\title{
Primary consumers and resources: Annual variation in two contrasting reaches of a Patagonian mountain stream
}

\author{
Verónica Díaz Villanueva ${ }^{1 *}$, Leonardo Buria ${ }^{2}$ and Ricardo Albariño ${ }^{1}$ \\ ${ }^{1}$ CONICET, INIBIOMA - Laboratory of Limnology, Universidad del Comahue Quintral 1250, 8400 Bariloche, Argentina \\ ${ }^{2}$ Dirección de Parques Nacionales, Argentina
}

Received 26 August 2009; Accepted 4 December 2009

\begin{abstract}
Resource availability influences the flow of energy through food webs, thus affecting biomass and trophic structure of consumer communities. To assess the effect of availability of allochthonous (leaf litter) and autochthonous (periphyton) resources on the trophic structure of macroinvertebrates, we sampled monthly for a year two sites (upstream forested, downstream open canopy) of Challhuaco, a low order mountain stream in the Patagonian Andes. Leaf litter and periphyton dynamics showed the expected pattern, peaking in autumn and spring, respectively. Temporal variations of shredders and scrapers were synchronized, with the logic delay, with resource abundance. Although leaf litter mass was similar at both stream reaches, shredders were more abundant at the forest site. Periphyton biomass was higher at the forest, while scrapers were more abundant at the open site. The patterns of resource and consumer abundance, and community functional structure were mostly explained by the interaction of abiotic factors and trophic relationships.
\end{abstract}

Key words: Functional feeding groups / benthic organic matter / periphyton / stream / Patagonia

\section{Introduction}

Temporal and spatial variations of the quantity and quality of food resources affect the flow of matter through food webs by setting dominant trophic interactions that are ultimately reflected in community structure (Power, 1992; Durant et al., 2005). In streams, resources to primary consumers come from the terrestrial surroundings (allochthonous detritus) and from autochthonous primary production. Forested headwater streams are highly dependent on allochthonous organic matter (Fisher and Likens, 1973; Wallace et al., 1999), while downstream reaches are greatly influenced by light availability allowing higher primary production (Vannote et al., 1980). This shift in the base of the food web would lead to differences in the relative abundance of primary consumers (herbivores and detritivores). Indeed, the "river continuum concept" (RCC) postulates that macroinvertebrates feeding on leaf litter (detritivorous shredders) will decrease from low order, forested streams to higher order streams with open canopy while grazers (mostly scrapers) are predicted to increase in biomass in the downstream open reaches (Vannote et al., 1980; Rosi-Marshall and Wallace, 2002). These changes have also been observed in streams affected

\footnotetext{
*Corresponding author: vdiazvilla@hotmail.com
}

by deforestation or fire (Townsend et al., 1997; Minshall, 2003; Benstead and Pringle, 2004).

Resources are variable in time, and this is well exemplified in temperate regions where the availability of leaf litter is seasonal with light inputs closely linked to litterfall (Hill and Dimick, 2002; Bernhardt and Likens, 2004; Roberts et al., 2004). In those streams, detritus and primary production dynamics are affected by terrestrial plant phenology (i.e. evergreen vs. deciduous forest). The RCC suggests that life cycles of the main functional feeding groups (FFGs) are coupled to the seasonal abundance of their favourite food. This idea was proposed as a testable hypothesis for the leaf litter - shredder link by Cummins et al. (1989) where maximum shredder biomass is expected to co-occur with appropriate conditioned litter (i.e. 50\% leaf litter mass loss in leaf breakdown experiments). Likewise, grazers are expected to follow primary production annual cycles (McIntire et al., 1996).

In many headwater streams of Patagonian Andes, the main primary consumers in terms of biomass are shredders and scrapers (Velázquez and Miserendino, 2003; Albariño and Díaz Villanueva, 2006; Miserendino, 2007). These two FFGs greatly differ in their ecological dynamics. While in herbivory producers and consumers control each other's dynamics, detritivory is a donor-controlled system so that the effect of consumption is only the reduction of resource 
(Begon et al., 1996; Rosemond et al., 2001). Thus, we would expect that shredders and scrapers respond differently to annual fluctuations of their resources, being shredder annual cycles linked to the highly seasonal input of allochthonous organic matter (Merritt and Cummins, 1996). On the contrary, scrapers would not only depend on periphytic dynamic, but also affect it, directly and indirectly (McIntire et al., 1996).

Our aim was to determine if the composition of invertebrate community, in particular the relative abundance of the main primary consumers in terms of biomass (i.e., shredders and scrapers), respond to annual variations in resources availability (leaf litter and periphyton), in two contrasting reaches of a mountain stream; the upstream reach runs through a deciduous forest whereas the downstream reach runs through a shrub-dominated area. Our predictions are that consumer's abundance will follow resource abundance, being shredders dominant in winter and scrapers in spring-summer. We aimed to test if differences in resource abundance (periphyton and leaf litter) due to differences in riparian cover may lead to differences in consumer community in two longitudinally connected sites.

\section{Methods}

\section{Study area}

Most headwaters in Patagonia are located in the Andes between 1000 and $1500 \mathrm{~m}$ a.s.l. where streams are canopied by deciduous endemic beeches of the genus Nothofagus (Modenutti et al., 1998; Albariño and Balseiro, 2002). The study was carried out in a low order stream of the Challhuaco catchment $\left(41^{\circ} 13^{\prime} \mathrm{S} ; 71^{\circ} 20^{\prime} \mathrm{W}\right)$, at $1100-1200 \mathrm{~m}$ a.s.l. where it drains an old growth Nothofagus pumilio (Poep. and Endl.) Krasser forest. In Patagonian Andes, this deciduous beech constitutes the highest mountain belt of the temperate forest, up to the timberline (Hildebrand-Vogel et al., 1990). The downstream reach vegetation is mostly dominated by Nothofagus antarctica (Forest.) Oerst., Schinus patagonica (Phil.) I.M. Johnst. and Diostea juncea (Gillies and Hook.) Miers. The hydrological regime presents peak discharges in autumn (rain) and spring (snowmelt) and the lowest values late in summer. Catchment parental material is composed of volcanic granite rocks and has fluvial origin. Stream morphology is variable alternating interspersed smooth step-pool habitats with a pool-riffle structure. Streambed roughness is determined by a dominance of cobbleboulder substrates but is additionally characterized at the forest extension by the presence of frequent wood logs.

\section{Samples collection}

Samples of macroinvertebrates, coarse particulate organic matter (CPOM) and periphyton were taken monthly from May 25th 2003 to April 25th 2004 in two reaches. The upstream site was located in the forest, corresponding to a second order stream. The open site (third order stream) was located $3.13 \mathrm{~km}$ downstream the forest site and $2.27 \mathrm{~km}$ far from the forest edge. At each sampling date and site, temperature, oxygen concentration and conductivity were measured with a multiprobe (YSI 85, Yellow Spring, Ohio). Water velocity was measured with a mechanical flowmeter (Hydro-Bios 438110 , Kiel-Holtenau, Germany) along a stream transversal transect (three measures each transect where one record integrated $30 \mathrm{~s}$ of propeller exposure). Wet width was measured at three transects separated every $5 \mathrm{~m}$ and channel depth was registered every $20 \mathrm{~cm}$ along the same transect with tape and graduate pole. Light intensity was recorded once in December and once in June, at midday, at each sampling site to compare the order of magnitude in difference between both sites. PAR incidence was averaged from the instantaneous measures collected with a QSL-2100 Irradiance Sensor (Biospherical Instruments, Inc., San Diego, California) along a longitudinal $30 \mathrm{~m}$ transect by wading the stream channel.

The exotic rainbow trout (Oncorhynchus mykiss Walbaum) is the only fish species found in the upper catchment with a stable population present at both sampling sites with similar densities (approx. 0.5 ind. $\mathrm{m}^{-2}$ ) and sizes (mean body length $\sim 10 \mathrm{~cm}$ ) (Buria et al., 2007).

\section{Resources}

Coarse particulate organic matter (CPOM) was collected together with the invertebrates by Surber sampling (described below). In the laboratory, it was fractionated by wet sieving (sieve $1 \mathrm{~mm}$ mesh size) and woody fragments, fruits and flowers were removed from the tray. Although these items may be important energy sources at certain periods (Collier and Halliday, 2000), we concentrated our effort on the leafy material as it represents the bulk of CPOM. Leaf litter was placed in containers, dried at $80^{\circ} \mathrm{C}$ for $48 \mathrm{~h}$ and weighed to the nearest $0.01 \mathrm{~g}$.

Algal biomass was estimated as chlorophyll $a$ concentration $(\mathrm{Chl} a)$ and periphyton organic matter as ash free dry mass (AFDM). Nine cobble-pebbles were randomly taken at each sampling reach and carried to the laboratory in individual containers, in dark and thermally isolated. Periphyton was scraped from the substrate with a nylon brush and washed with distilled water. The sample was then homogenised and an aliquot of $1 \mathrm{~mL}$ was used for Chl $a$ estimation. Extraction was done with hot $90 \%$ ethanol and freezing for $24 \mathrm{~h}$, following Nusch (1980). Measurements were carried out in a fluorometer (Turner designs 10-AU, Sunnyvale, USA). Periphyton AFDM was determined by filtering an aliquot of $5 \mathrm{~mL}$ onto preweighed and pre-combusted Whatman GF/C filters and dried at $80^{\circ} \mathrm{C}$ for $48 \mathrm{~h}$. The filters were weighed, combusted at $550{ }^{\circ} \mathrm{C}$ for $1 \mathrm{~h}$ and re-weighed, considering that AFDM was the difference in mass before and after incineration (APHA, 1989). The rest of the sample was preserved in $4 \%$ formalin for the analysis of 
Table 1. Annual physical variables (maximum, minimum and mean) in the Forest and Open reaches of the Challhuaco tributary stream. PAR: photosynthetic active radiation.

\begin{tabular}{llcc}
\hline & & Forest & Open \\
\hline Light intensity & Summer & 214 & 2000 \\
$\mu$ E.m ${ }^{-2} \cdot \mathrm{s}^{-1}(\mathrm{PAR})$ & Late autumn & 319 & 619 \\
\hline \multirow{2}{*}{ Temperature $\left({ }^{\circ} \mathrm{C}\right)$} & Maximum & 10 & 13 \\
& Minimum & 4 & 5 \\
& Average & 7 & 7 \\
& Maximum & 65 & 50 \\
Conductivity $\left(\mu \mathrm{S} . \mathrm{cm}^{-1}\right)$ & Minimum & 45 & 45 \\
& Average & 58 & 48 \\
& & & \\
Oxygen $\left(\mathrm{mg} . \mathrm{L}^{-1}\right)$ & & 10.5 & 10.5 \\
& & & \\
& & 84 & 99 \\
Current velocity $\left(\mathrm{cm} . \mathrm{s}^{-1}\right)$ & Maximum & 35 & 44 \\
& Average & 53 & 68 \\
& & & \\
& Maximum & 4.7 & 9.7 \\
Mean width $(\mathrm{m})$ & Minimum & 1.8 & 5.1 \\
& Average & 3.1 & 7.4 \\
& & & \\
& Maximum & 29 & 64 \\
Mean depth $(\mathrm{cm})$ & Minimum & 9 & 21 \\
& Average & 17 & 39 \\
\hline
\end{tabular}

algal assemblage. Cell counting was performed under a direct microscope at $400 \times$ of magnification. More than 1000 algal cells were counted to estimate the relative abundance of the different taxa. The total surface of cobbles was estimated from the three main orthogonal axes (Graham et al., 1988). To estimate the colonized surface, we considered that only $2 / 3$ of the surface was available for algal growth (Biggs and Close, 1989).

\section{Invertebrate consumers}

Benthic aquatic invertebrates were collected with a Surber sampler $\left(0.09 \mathrm{~m}^{2}, 200 \mu \mathrm{m}\right.$ mesh size $)$. Five replicates were taken at each site at erosional habitats: runs and riffles. Samples were preserved in $5 \%$ formalin until processing. In the laboratory, all invertebrates were sorted, identified to the lowest possible taxonomic level, and counted. Individuals of each taxa were dried at $80^{\circ} \mathrm{C}$ for $24 \mathrm{~h}$ and weighed to the nearest $0.01 \mathrm{mg}$ to estimate invertebrate biomass.

Additionally, invertebrates were assigned to functional feeding groups (FFGs). For this purpose, we used local bibliography when available (Díaz Villanueva and Albariño, 1999; Albariño, 2001; Velázquez and Miserendino, 2003; Díaz Villanueva et al., 2004) or gut content analyses and mouthparts morphology observations complemented with bibliography from the Southern Hemisphere (Thompson and Townsend, 1999).

\section{Statistical analysis}

Differences in biofilm Chl $a$ concentration and AFDM, leaf litter mass and FFGs biomass among months were analysed by RM-ANOVAs. Data were log-transformed to obtain normality. Significant differences were considered when $P<0.05$.

Communities from both sites were compared calculating the difference between the average of all dissimilarities between samples among groups and the average of all dissimilarities between samples within groups (Quinn and Keough, 2002) using a two-way crossed ANOSIM, where factors were sampling sites and months (Primer 5 package, Plymouth Marine laboratory, Plymouth, UK).

\section{Results}

Light intensity (PAR) varied more in the open site than in the forest. In the open site it was $2000 \mu \mathrm{E} \cdot \mathrm{m}^{-2} \cdot \mathrm{s}^{-1}$ in December (summer) and $612 \mu \mathrm{E} \cdot \mathrm{m}^{-2} \cdot \mathrm{s}^{-1}$ in June (late autumn) while in the forest, it was similar in both seasons (Table 1). Water temperature varied according to the season; the lowest values were found in winter in the forest $\left(4^{\circ} \mathrm{C}\right)$ and the highest in February (late summer) in the open $\left(13^{\circ} \mathrm{C}\right)$, when the difference between sampling sites were the highest $\left(\Delta \mathrm{T}=3^{\circ} \mathrm{C}\right)$ (Table 1$)$. Water velocity, width and depth of the channel also varied according to the hydrological regime; the highest values were registered in October and November (snowmelt) and the lowest from January to March (Table 1). Conductivity was low (Table 1), and it was lower at the downstream site because of the more diluted condition of waters from a tributary stream between both sites. Dissolved oxygen was always at saturation level (Table 1).

The annual pattern of CPOM showed an expected peak in May following leaf fall in the forest, and it was similar in the open reach (RM-ANOVA, $P=0.700$, Fig. 1). We also found a similar leaf litter composition, dominated by $N$. pumilio leaves, which indicates homogeneous detritus quality in both reaches in terms of leaf species identity. However, maximum CPOM mass decreased from 34.10 g.m ${ }^{-2}$ at the forest to 23.33 g.m ${ }^{-2}$ at the open site, representing a $30 \%$ of loss in $3 \mathrm{~km}$ downstream. In the summer months (December to February), on the contrary, CPOM was lower at the forest than at the open.

Periphyton peaked in September, just before the leafout, at the same time at both sites. Both Chl a concentration and AFDM were much higher at the forest (RM-ANOVA, $P<0.001$ and $P=0.037$ respectively, Fig. 2). The abrupt decline of periphytic biomass at both sites in October might be caused by the increase in water discharge due to snowmelt. From April to August periphytic biomass was similar at both sites, which coincided with the absence of leaves in the trees and less differences in light intensity (Table 1). The proportion of Chl $a$ in the periphyton matrix was similar at both sites (RM-ANOVA, $P=0.067$, Fig. 2c). 


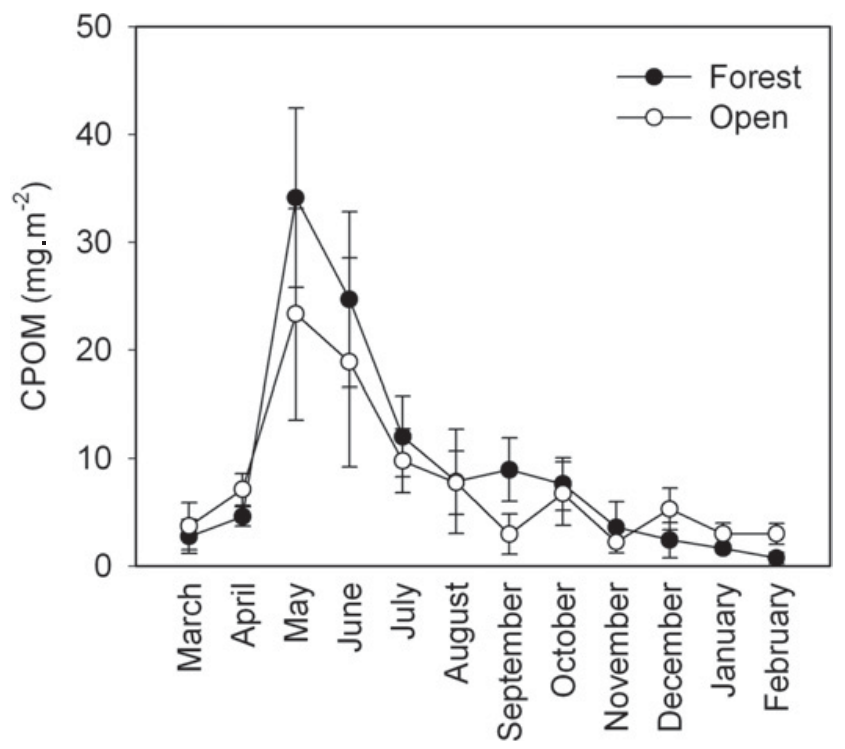

Fig. 1. Monthly standing stock of coarse benthic organic matter $(\mathrm{CPOM})$ at two sites differing in forest cover. Error bars $=1$ standard error.

Periphyton species composition presented a relatively similar pattern at both sites. However, algal communities differed in the relative abundance of the most representative taxa throughout the year (Table 2). In the forest, diatoms were the dominant group all year long except from August to October when the filamentous algae Hydrurus foetidus (Vill.) Trev. (Chrysophyta) and Ulotrix sp. (Chlorophyta) co-dominated. Filamentous cyanophytes were scarce during the year but during June-July they reached $20 \%$. In the open, diatoms dominated in summer $(100 \%)$ but from June to September they were surpassed by $H$. foetidus, which peaked in August (85\%), compared to the forested site where they peaked in October $(78 \%)$. Filamentous chlorophytes and cyanophytes were proportionally less important than in the forested site (Table 2).

Invertebrate density was highest at the forest site (RM-ANOVA, $P=0.002$ ) where it reached 8450 ind. $\mathrm{m}^{-2}$ in summer, while in winter it fell below 1500 ind. $\mathrm{m}^{-2}$ (Fig. 3a). Total biomass was similar at both sites (RMANOVA, $P=0.298$ ); however, there was a peak at the open site in November (Fig. 3b) caused by a high individual biomass (Fig. 3c).

The community structure differed among months (twoway crossed ANOSIM, global rho $=0.756, P=0.001$ ); however, invertebrate species composition (Table 3) was almost similar at both stream reaches. Differences in structure were reflected in differences in the FFGs. In the forest, there was not a consistent dominance of any FFG, but the shredders were the most abundant during autumnwinter and collector-gatherers during spring-summer (Fig. 4). Shredders total biomass was significantly higher at the forest (RM-ANOVA, $P=0.035$, Fig. 5a). In particular, the shredder Klapopteryx kuscheli (Illies 1960) (Plecoptera) was abundant year round in the forest (up to

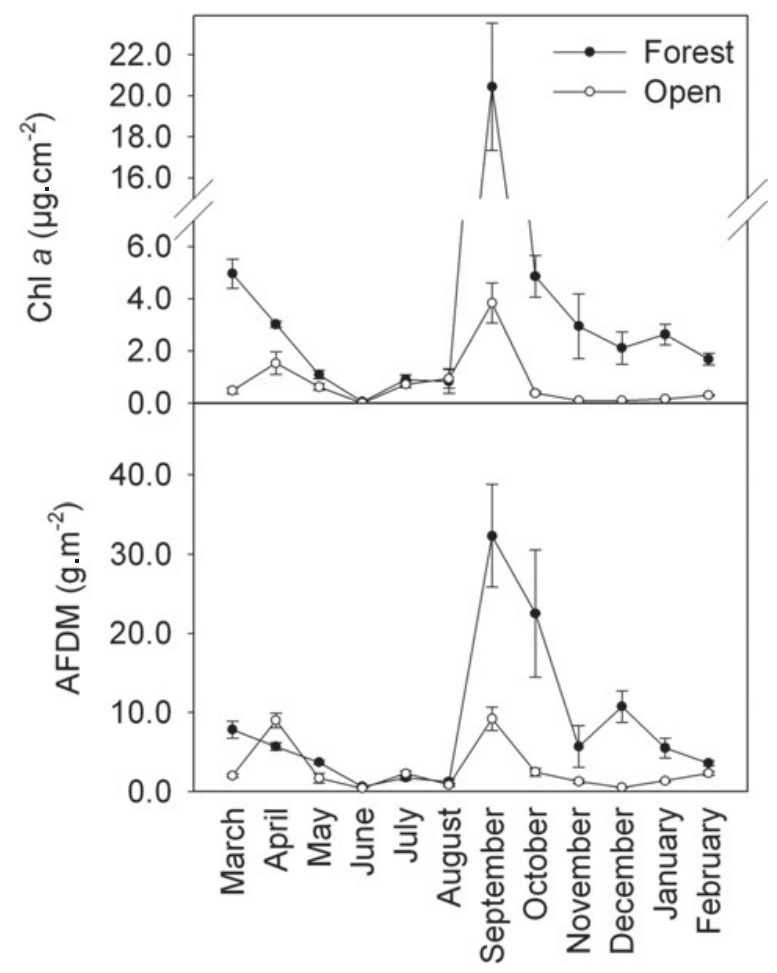

Fig. 2. Monthly abundance in Chlorophyll $a$ and AFDM of periphyton at two sites differing in forest cover. Error bars $=1$ standard error.

$47 \%$ in May), and in terms of density, two chironomid morpho-species (collector-gatherers) dominated (chironomids reached $80 \%$ of total individuals in December). On the contrary, the open reach was dominated by scrapers during the whole year (Fig. 4) and their biomass was higher at this site (RM-ANOVA, $P=0.016$, Fig. $5 b$ ). In terms of density, the most abundant taxa were plecopterans, chironomids and oligochaetes. In particular, the scraper Notoperla archiplatae (Illies 1958) (Plecoptera) reached up to $96 \%$ in November.

The maximum annual biomass of shredders and grazers showed a delay relative to the peaks in ambient abundance of their main food resources. The highest shredder's biomass was achieved in July (open site) and in August (forest) (Fig. 5a) while leaf litter had peaked in May (Fig. 1). Scraper's biomass was greatest in November (open site) and October (forest) (Fig. 5b) while periphyton had peaked in September (Fig. 2).

\section{Discussion}

Benthic leaf litter annual dynamic was very predictable, showing a marked peak in May (leaf abscission time) and a progressive reduction until April next year. Particularly during summer, we found lower amounts of leaf litter in the forest. As detritivory represents a donorcontrolled system we expected that shredder annual cycles were linked to the highly seasonal input of allochthonous organic matter. In accordance to the model of leaf 
Table 2. Abundance (\%) of the different algal groups at both study sites along the year.

\begin{tabular}{|c|c|c|c|c|c|c|c|c|}
\hline \multirow[b]{2}{*}{$\%$} & \multicolumn{4}{|c|}{ Forest } & \multicolumn{4}{|c|}{ Open } \\
\hline & $\overline{\text { Diatoms }}$ & Hydrurus & Chlorophyta & Cyanophyta & Diatoms & Hydrurus & Chlorophyta & Cyanophyta \\
\hline$\overline{\text { March }}$ & 90 & 0 & 0 & 10 & 100 & 0 & 0 & 0 \\
\hline April & 90 & 5 & 3 & 2 & 60 & 40 & 0 & 0 \\
\hline May & 95 & 5 & 0 & 0 & 95 & 4 & $<1$ & $<1$ \\
\hline June & 85 & 0 & 0 & 15 & 50 & 50 & 0 & 0 \\
\hline July & 80 & 0 & 0 & 20 & 40 & 60 & 0 & 0 \\
\hline August & 50 & 50 & 0 & 0 & 15 & 85 & 0 & 0 \\
\hline September & 20 & 30 & 50 & 0 & 25 & 50 & 25 & 0 \\
\hline October & 25 & 70 & 5 & 0 & 80 & 10 & 10 & 0 \\
\hline November & 80 & 15 & 1 & 4 & 60 & 30 & 10 & 0 \\
\hline December & 55 & 40 & 5 & 0 & 60 & 40 & 0 & 0 \\
\hline January & 90 & 0 & 0 & 10 & 100 & 0 & 0 & 0 \\
\hline February & 93 & 0 & 0 & 7 & 100 & 0 & 0 & 0 \\
\hline
\end{tabular}

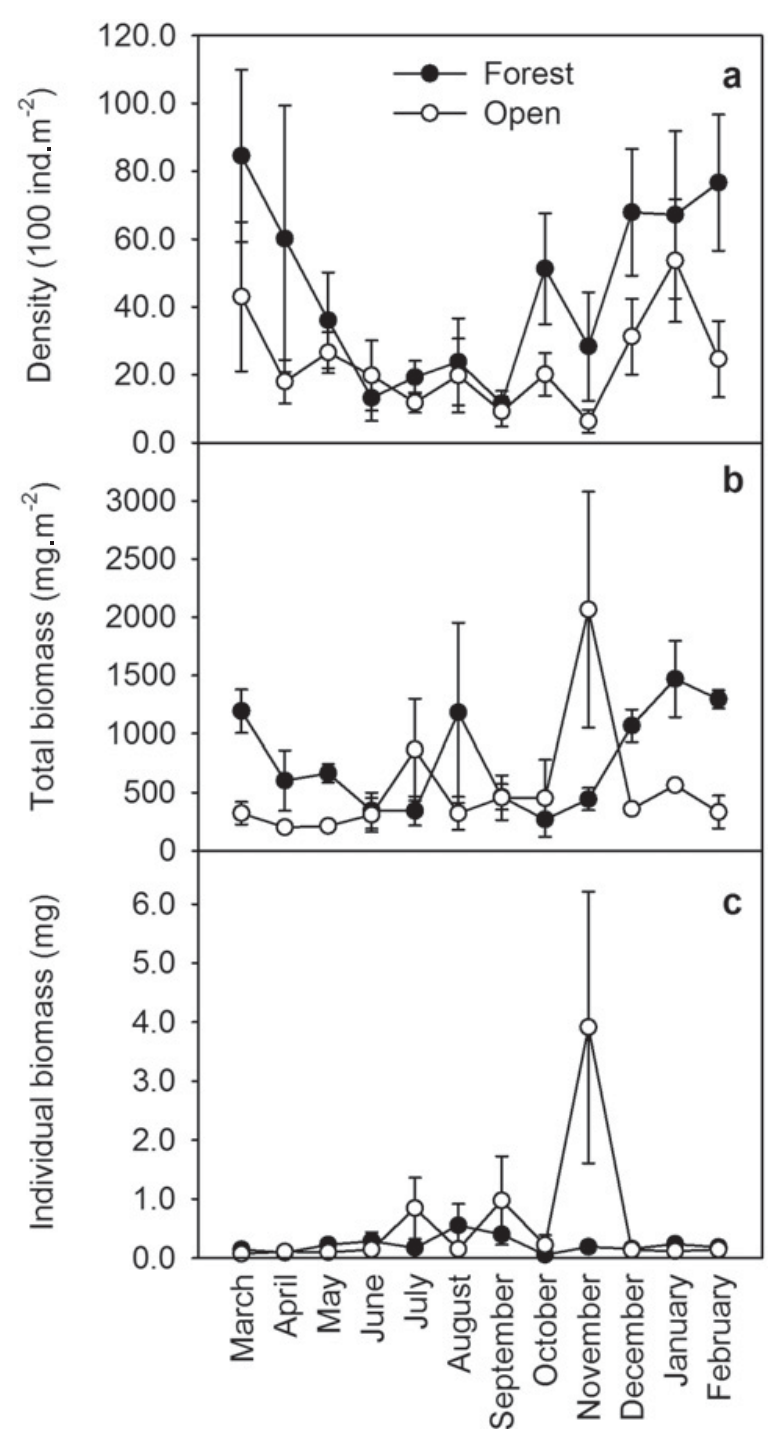

Fig. 3. Monthly standing crop of benthic invertebrates: community density (a) and biomass (b), and average mass of individual invertebrates (c) at two sites differing in forest cover. Error bars $=1$ standard error. litter-detritivore dynamics in streams proposed by Cummins et al. (1989), there was a peak of shredders biomass in August, three months after leaf litter input. This pattern was also found in a nearby stream, where the biomass of the shredder $K$. kuscheli peaked in winter (Albariño and Díaz Villanueva, 2006). The delay would reflect the timing of $N$. pumilio leaf litter conditioning, which has been estimated in two to three months (Albariño and Balseiro, 2002).

Amounts of CPOM in the open site were similar to those of the forest. We would expect significantly higher leaf detritus in forested than in open, downstream reaches (Stout et al., 1993; Townsend et al., 1997; Benstead et al., 2003). However, downstream movement of detritus is a major phenomenon in lotic systems. Studies on leaf litter dynamics have shown that leaves may stay in a single spot until they breakdown or may be transported short or long distances (Webster et al., 1999) in a downstream direction depending on stream retentiveness. The ability of a stream to store organic detritus results from characteristics of channel morphology and hydrological regime (Larrañaga et al., 2003) and high discharges may remove and redistribute large amounts of leaf litter exporting significant quantities further downstream of the point of origin (Fischer and Likens, 1973; Webster et al., 1997). This may be a common seasonal pattern in Andean Patagonian headwaters as the rainy period starts at the end of leaf shedding time and causes terrestrial litter to redistribute along the stream channel. In wet years, significant amounts of leaves originated in the mountain forest of Challhuaco-Nireco valleys may be collected more than $15 \mathrm{~km}$ downstream from the lower forest limit (R. Albariño, unpublished). Such events explain our findings of almost as much CPOM in the open as in the wood, only $2 \mathrm{~km}$ downstream the limit of the forest.

However, the biomass of shredders was much lower at the open site, indicating that factors other than resources can determine the abundance of consumers. It is plausible that this pattern responds to behavioural traits such as selective oviposition by females in well-shaded reaches 
Table 3. Invertebrate taxa at both sampling sites along the year of study with the assigned functional feeding group (FFG); SC: scraper; Sh: shredder; CG: collector gatherer; CF: collector filterer; Pr: predator.

\begin{tabular}{|c|c|c|c|}
\hline & FFG & & $\overline{\text { FFG }}$ \\
\hline \multicolumn{4}{|l|}{ Ephemeroptera } \\
\hline Baetidae & & Ceratopogonidae & $\operatorname{Pr}$ \\
\hline Andesiops peruvianus & $\mathrm{Sc}$ & Chironomidae sp. 1 to 5 & $\mathrm{CG}$ \\
\hline Andesiops torrens & $\mathrm{Sc}$ & Tanypodinae sp. 1 & $\operatorname{Pr}$ \\
\hline Nesameletidae & & Empididae sp. 1 and 2 & $\operatorname{Pr}$ \\
\hline Metamonius anceps & $\mathrm{Sc}$ & Simulidae spp. & $\mathrm{CF}$ \\
\hline Leptophlebiidae & & Coleoptera & \\
\hline Meridialaris chiloeensis & $\mathrm{Sc}$ & Elmidae sp. 1 and 2 & $\mathrm{CG}$ \\
\hline Plecoptera & & Scirtidae & $\mathrm{CG}$ \\
\hline Notonemouridae & & Trichoptera & \\
\hline Austronemoura sp. & $\mathrm{Sh}$ & Hydrobiosidae & \\
\hline Udamocercia sp. & $\mathrm{Sh}$ & Neoatopsyche sp. 1 and 2 & $\operatorname{Pr}$ \\
\hline Austroperlidae & & Hydropsychidae & \\
\hline Klapopteyx kuscheli & $\mathrm{Sh}$ & Smicridea sp. & $\mathrm{CF}$ \\
\hline Gripopterygidae & & Leptoceridae & \\
\hline Antarctoperla michaelseni & $\mathrm{Sh}$ & Brachysetodes major & $\mathrm{CG}$ \\
\hline Aubertoperla illiesi & $\mathrm{Sc}$ & Limnephilidae & \\
\hline Limnoperla jaffueli & $\mathrm{Sc}$ & Monocosmoecus sp. & Sh \\
\hline Notoperla archiplatae & $\mathrm{Sc}$ & Sericostomatidae & \\
\hline Pelurgoperla personata & $\mathrm{CG}$ & Myotrichia murina & $\mathrm{Sh}$ \\
\hline Diptera & & Parasericostoma cristatum & Sh \\
\hline \multicolumn{4}{|l|}{ Athericidae } \\
\hline Dasyomma sp. & $\operatorname{Pr}$ & & \\
\hline Tipulidae & & Others & \\
\hline Molophylus sp. & Sh & Oligochaeta & $\mathrm{CG}$ \\
\hline Tipula sp. & Sh & Turbellaria & \\
\hline Limoniinae sp. 1 to 2 & Sh & Romankenkius sp. & $\operatorname{Pr}$ \\
\hline
\end{tabular}

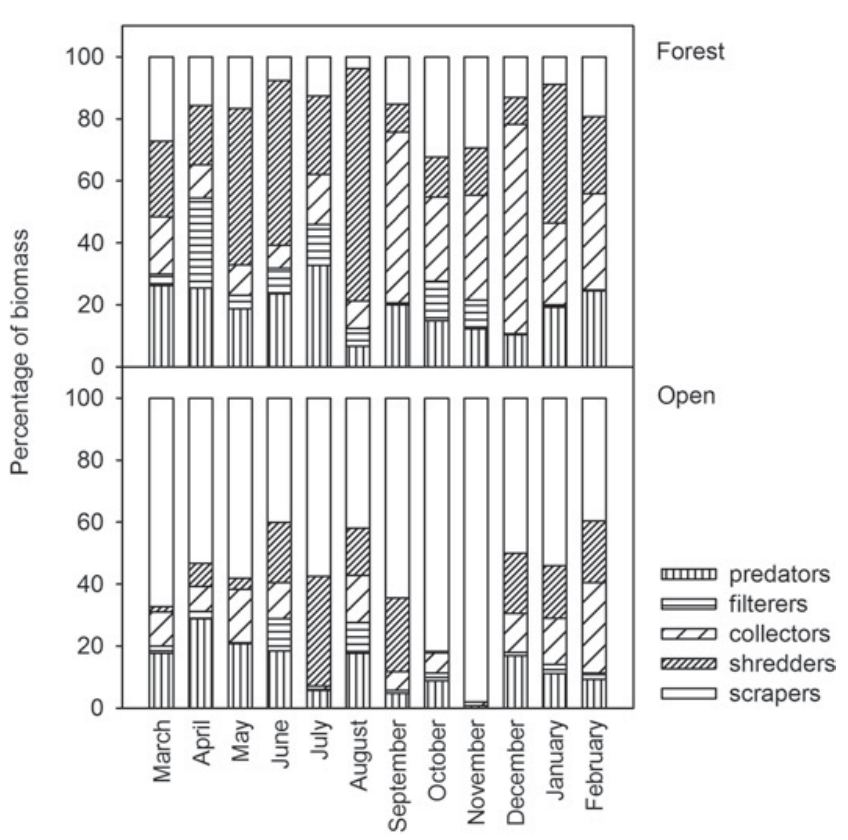

Fig. 4. Functional structure of the benthic community referred as percentage in biomass of the functional feeding groups through the year at two sites differing in forest cover.

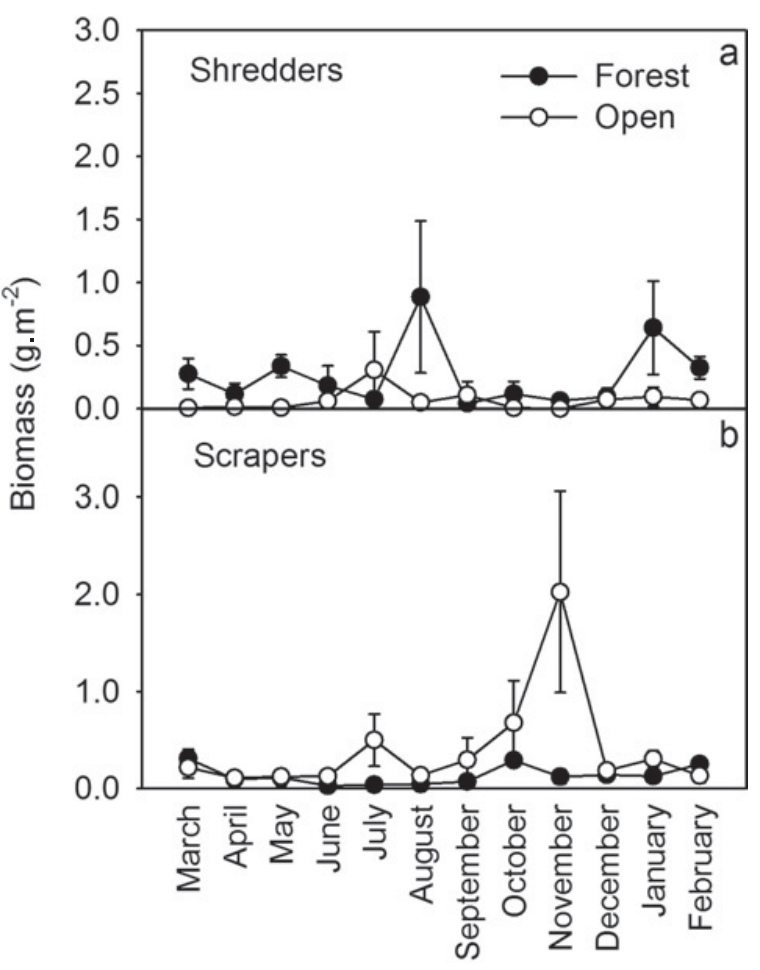

Fig. 5. Total biomass of a) shredders and b) scrapers through the year at two sites differing in forest cover. Error bars $=1$ standard error. 
(Williams and Felmate, 1994), or differences in water velocity preferences (Basaguren et al., 1996). Shredders may also find better quality food in the forest. Albariño et al. (2008) experimentally showed that larvae of $K$. kuscheli grew faster with a diet of leaves that had been conditioned under shade compared to those fed with leaves conditioned under sunlight.

In the open site, scrapers dominated throughout the year. Although periphytic biomass reached its maximum value in September, primary production was expected to occur all year long (with its seasonal variations), contrarily to allochthonous organic matter inputs and availability. However, a temporal response in scrapers biomass tracking higher periphytic abundance did happen. In particular, $N$. archiplatae reached its maximum individual (and total) biomass in November, two months after algae peaked. In a neighbour catchment, $N$. archiplatae also reached maximum biomass in spring (Albariño and Díaz Villanueva, 2006). Therefore, life cycle of $N$. archiplatae seems quite associated to periphyton dynamic of open reaches.

Several factors, including light, nutrient, water velocity and grazing activity (Stevenson, 1996), may have contributed to the highest values found in the forested section compared to the open reach. High light intensity in the open might have caused photoinhibition; nutrients were not measured but a higher conductivity in the forest could be due to a higher nutrient concentration; higher water velocity at the open site could cause more frequent and severe sloughing events. Ultimately, the higher abundance of scrapers in the open should exert a more intense grazing pressure, diminishing algal biomass. Despite the highest algal biomass in the forest site, biomass of scrapers was higher in the open reach. As periphyton was dominated by diatoms and $H$. foetidus in both sites we cannot attribute this mismatch to differences in periphyton composition, which may lead to differences in biofilm palatability (Steinman, 1996) and quality (Lamberti, 1996). Light energy usually leads to higher grazer biomass instead of an increase in periphyton biomass, which can even decrease slightly (McIntire et al., 1996; Wellnitz et al., 1996; Hillebrand, 2005). Thus, the higher biomass of scrapers in the open could indicate a higher primary production, which was allocated into consumer biomass.

The quantitative and qualitative importance of allochthonous and autochthonous energy sources changes seasonally and spatially (Power, 1992). This seasonality in resource availability was evident at both stream reaches and was reflected in the relative abundances of the different FFGs in the forest, where shredders dominated total community biomass in autumn-winter and collectorgatherers in spring-summer.

Trophic structure of invertebrates was the predicted by current models, being shredders more abundant in the forest and scrapers in the open reaches. The patterns between resource abundance and consumer abundance or community structure were mostly explained by dynamic trophic interactions. Our study showed that those interactions act across spatial and temporal axes within the fluvial system where primary consumer abundances reflected the spatial distribution of basal resources following a temporal delay.

Acknowledgements. This work was supported by Fondo para la Investigación Científica (FONCyT) PICT 2007-01747, and CONICET, PIP 112-200801-01702. V. Díaz Villanueva and R. Albariño are CONICET researchers.

\section{References}

Albariño R.J., 2001. Food habit and mouthpart morphology of a South Andes population of Klapopteryx kuscheli (Plecoptera: Austroperlidae). Aquat. Insects, 23, 171-181.

Albariño R.J. and Balseiro E.G., 2002. Leaf litter breakdown in Patagonian streams: native versus exotic trees and the effect of invertebrate size. Aquat. Conserv., 12, 181-192.

Albariño R.J. and Díaz Villanueva V., 2006. Feeding ecology of two plecopterans in low order Andean-Patagonian streams. Internat. Rev. Hydrobiol., 91, 122-135.

Albariño R.J., Díaz Villanueva V. and Canhoto C., 2008. The effect of sunlight on leaf litter quality reduces growth of the shredder Klapopteryx kuscheli. Freshw. Biol., 53, 1881-1889.

APHA (American Public Health Association), 1989. Standard methods for the examination of water, sewage, and wastewater, American Public Health Association, Washington D.C.

Basaguren A., Elosegui A. and Pozo J., 1996. Changes in the trophic structure of benthic macroinvertebrate communities associated with food availability and stream flow variations. Int. Rev. Ges. Hydrobiol., 81, 1-12.

Begon M., Harper J.L. and Townsend C.R., 1996. Ecology: Individuals, Populations and Communities, Blackwell Publishing, Inc., 1068 p.

Benstead J.P. and Pringle C.M., 2004. Deforestation alters the resource base and biomass of endemic stream insects in eastern Madagascar. Freshw. Biol., 49, 490-501.

Benstead J.P., Douglas M.M. and Pringle C.M., 2003. Relationship of stream invertebrate communities to deforestation in eastern Madagascar. Ecol. Appl., 13, 1473-1490.

Bernhardt E.S. and Likens G.E., 2004. Controls on periphyton biomass in heterotrophic streams. Freshw. Biol., 49, 14-27.

Biggs B.J. and Close M.E., 1989. Periphyton biomass dynamics in gravel bed rivers: the relative effects of flow and nutrients. Freshw. Biol., 22, 209-231.

Buria L., Albariño J.R., Díaz Villanueva V., Modenutti B. and Balseiro E., 2007. Impact of exotic rainbow trout on the benthic macroinvertebrate community from AndeanPatagonian headwater streams. Arch. Hydrobiol., 168, 145154.

Collier K.J. and Halliday J.N., 2000. Macroinvertebrate-wood associations during decay of plantation pine in New Zealand pumice-bed stream: stable habitat or trophic subsidy? J. N. Am. Benthol. Soc., 19, 94-111.

Cummins K.W., Wilzbach M.A., Gates D.M., Perry J.B. and Taliaferro W.B., 1989. Shredders and riparian vegetation. BioScience, 39, 24-30.

Díaz Villanueva V. and Albariño R.J., 1999. Feeding habit of Notoperla archiplatae (Plecoptera) larvae in a North Patagonia Andean stream, Argentina. Hydrobiologia, 412, $43-52$. 
Díaz Villanueva V., Albariño R. and Modenutti B., 2004. Grazing impact of two aquatic invertebrates on periphyton from an Andean-Patagonian stream. Arch. Hydrobiol., 159, 455-471.

Durant J.M., Hjermann D.Ø., Anker-Nilssen T., Beaugrand G., Mysterud A., Pettorelli N. and Stenseth N.C., 2005. Timing and abundance as key mechanisms affecting trophic interactions in variable environments. Ecol. Lett., 8, 952-958.

Fisher S.G. and Likens G.E., 1973. Energy flow in Bear Brook, New Hampshire: An integrative approach to stream ecosystem metabolism. Ecol. Monogr., 43, 421-439.

Graham A.A., McCaughan D.J. and McKee F.S., 1988. Measurement of surface area of stones. Hydrobiologia, 157, 85-87.

Hildebrand-Vogel R., Godoy R. and Vogel A., 1990. Subantarctic-Andean Nothofagus pumilio forests. Distribution area and systematic overview, vegetation and soils as demonstrated by an example of a South Chilean stand. Vegetation, $89,55-68$.

Hill W.R. and Dimick S.M., 2002. Effects of riparian leaf dynamics on periphyton photosynthesis and light utilisation efficiency. Freshw. Biol., 47, 1245-1256.

Hillebrand H., 2005. Light regime and consumer control of autotrophic biomass. J. Ecology, 93, 758-69.

Lamberti G.A., 1996. The role of periphyton in benthic food webs. In: Stevenson R.J., Bothwell M.L. and Lowe R.L. (eds.), Algal Ecology: Freshwater Benthic Ecosystems, Academic Press, San Diego, 533-573.

Larrañaga S., Díez J.R., Elosegui A. and Pozo J., 2003. Leaf retention in streams of the Agüera basin (northern Spain). Aquat. Sci., 65, 158-166.

McIntire C.D., Gregory S.V., Steinman A.D. and Lamberti G.A., 1996. Modeling benthic algal communities: an example from stream ecology. In: Stevenson R.J., Bothwell M.L. and Lowe R.L. (eds.), Algal Ecology: Freshwater Benthic Ecosystems, Academic Press, San Diego, 670-704.

Merritt R.W. and Cummins K.W., 1996. An Introduction to the Aquatic Insects of North America, Kendall/Hunt Publishing Company, Dubuque, $862 \mathrm{p}$.

Minshall G.W., 2003. Responses of stream benthic macroinvertebrates to fire. Forest Ecol. Manage., 178, 155-161.

Miserendino M.L., 2007. Macroinvertebrate functional organization and water quality in a large arid river from Patagonia (Argentina). Ann. Limnol. - Int. J. Lim., 43, 133145.

Modenutti B.E., Balseiro E.G., Queimaliños C.P., Añón Suárez D.A., Diéguez M.C. and Albariño R.J., 1998. Structure and dynamics of food web in Andean lakes. Lakes Reserv.: Res. Manage., 3, 179-186.

Nusch E.A., 1980. Comparison of different methods for chlorophyll and phaeopigment determination. Arch. Hydrobiol. Beih. Ergebn. Limnol., 14, 14-36.

Power M.E., 1992. Top-down and bottom-up forces in food webs: do plants have primacy? Ecology, 73, 733-746.
Quinn G. and Keough M., 2002. Experimental design and data analysis for biologist, Cambridge University Press, 537 p.

Roberts S., Sabater S. and Beardall J., 2004. Benthic microalgal colonization in streams of differing riparian cover and light availability. J. Phycol., 40, 1004-1012.

Rosemond A., Pringle C., Ramirez A. and Paul M., 2001. A test of top-down and bottom-up control in a detritus-based food web. Ecology, 82, 2279-2293.

Rosi-Marshall E.J. and Wallace J.B., 2002. Invertebrate food webs along a stream resource gradient. Freshw. Biol., 47, 129-141.

Steinman A.D., 1996. Effects of grazers on freshwater benthic algae. In: Stevenson R.J., Bothwell M.L. and Lowe R.L. (eds.), Algal Ecology: Freshwater Benthic Ecosystems, Academic Press, San Diego, 341-374.

Stevenson R.J., 1996. The stimulation and drag of current. In: Stevenson R.J., Bothwell M.L. and Lowe R.L. (eds.), Algal Ecology: Freshwater Benthic Ecosystems, Academic Press, San Diego, 321-340.

Stout B., Benfield E.F. and Webster J.R., 1993. Effects of a forest disturbance on shredder production in southern Appalachian headwater streams. Freshw. Biol., 29, 59-69.

Thompson R.M. and Townsend C.R., 1999. The effect of seasonal variation on the community structure and foodweb attributes of two streams: implications for food-web science. Oikos, 87, 75-88.

Townsend C.R., Arbuckle C.J., Crowl T.A. and Scarsbrook M.R., 1997. The relationship between land use and physicochemistry, food resources and macroinvertebrate communities in tributaries of the Taieri River, New Zealand: A hierarchically scaled approach. Freshw. Biol., 37, 177-191.

Vannote R.L., Minshall G.W., Cummins K.W., Sedell J.R. and Cushing C.E., 1980. The River Continuum Concept. Can. J. Fish. Aquat. Sci., 37, 130-137.

Velázquez S.M. and Miserendino M.L., 2003. Habitat type and macroinvertebrate assemblages in low order Patagonian streams. Arch. Hydrobiol., 158, 461-83.

Wallace J.B., Eggert S.L., Meyer J.L. and Webster J.R., 1999. Effects of resource limitation on a detrital-based ecosystem. Ecol. Monogr., 69, 409-442.

Webster J.R., Meyer J.L., Wallace J.B. and Benfield E., 1997. Organic matter dynamics in Hugh White Creek, Coweeta Hydrologic Laboratory, North Carolina, USA. J. N. Am. Benthol. Soc., 16, 74-78.

Webster J.R., Benfield E.F., Ehrman T.P., Schaeffer M.A., Tank J.L., Hutchens J.J. and D'Angelo D.J., 1999. What happens to allochthonous material that falls into streams? A synthesis of new and published information from Coweeta. Freshw. Biol., 41, 687-705.

Wellnitz T.A., Rader R.B. and Ward J.V., 1996. Importance of light and nutrients in structuring an algal community in a Rocky Mountain stream. J. Freshwater Ecol., 11, 399-413.

Williams D.D. and Felmate B.W., 1994. Aquatic Insects, Cab International, Oxon, 358 p. 